\section{Construction and testing of the measurement system for excavator productivity}

The Mining-Geology-Petroleum Engineering Bulletin UDC: $622: 621$

DOI: 10.17794/rgn.2019.2.6

Original scientific paper

\author{
Mario Klanfar'; Vjekoslav Herceg²; Dalibor Kuhinek²; Kristijan Sekulić ${ }^{4}$ \\ ${ }^{1}$ University of Zagreb, Faculty of mining, geology and petroleum engineering, Pierottijeva 6, Zagreb, Assistant Professor \\ ${ }^{2}$ University of Zagreb, Faculty of mining, geology and petroleum engineering, Pierottijeva 6, Zagreb, Assistant \\ ${ }^{3}$ University of Zagreb, Faculty of mining, geology and petroleum engineering, Pierottijeva 6, Zagreb, Associate Proffesor \\ ${ }^{4}$ University of Zagreb, Faculty of mining, geology and petroleum engineering, Pierottijeva 6, Zagreb, Student
}

\begin{abstract}
A hydraulic excavator is one of the most used machines in mining, construction and geotechnics. Monitoring its productivity can provide benefits such as savings in fuel consumption and maintenance, cost optimization of working parameters and a higher working efficiency. A measurement system for such a purpose can be complex and expensive, as it requires special equipment from the manufacturer and does not exist as an out of the box solution that would measure working parameters such as bucket trajectory, digging energy, digging force, etc.

A measuring system was designed to monitor productivity and gather working parameters. It consists of three pressure transmitters for measuring cylinder pressures, three draw wire sensors for cylinder elongations, one inertial measurement unit for the measurement of swing angle and one logger unit for data acquisition and storage. The logger unit, equipped with an SD card module and 12-bit AD converter, is based on Atmegaz28 microcontroller, which allows for the usage of Arduino IDE and already developed libraries.

The system was tested in a laboratory to determine its accuracy, resolution and usable sample rate. Cylinder pressure can be measured in the range of o-50o bar with an excellent accuracy of $0.026 \%$ FSO and 0.15 bar resolution. Cylinder elongation can be measured in the range $0-2300 \mathrm{~mm}$ with an accuracy of $0.087 \%$ FSO and $0.58 \mathrm{~mm}$ resolution. Swing angle measurement accuracy is $1.2^{\circ}$ per circle or $0.33 \%$ FSO. The usable sample rate of the system is found to be $39 \mathrm{~Hz}-588 \mathrm{~Hz}$, depending on the logger executing code.
\end{abstract}

Keywords:

mining, excavator, productivity, measurement system.

\section{Introduction}

The productivity of mining equipment depends on many different factors. One of the most important is the force of interaction between the working tool and the rock mass. Korman et al. (2015) was investigating the forces of cutting rock by chain saw, Antoljak et al. (2018) explores the forces of interaction during rock drilling and Richardson-Little and Damaren (2008) describes soil-bucket interaction forces at digging.

A hydraulic excavator is the one of the most used pieces of equipment in mining, construction and geotechnics. Basically, it consists of a traveling body, swing body and front digging manipulator (see Figure 1) which includes three links: boom, arm and bucket (Mitrev et al., 2017). The main advantage of this machine is multifunctionality (Soon-Kwang et al., 2008) based on its robust design, adapting to field work and its ability to use different work tools. The bucket is the most

Corresponding author: Mario Klanfar

mario.klanfar@rgn.hr used working tool for digging, loading and moving different types of materials.

Measuring the productivity of an excavator can provide several benefits. First of all, the simplest definition of an excavator's productivity is the quantity of material that the excavator can move, dig or load in a certain time. This information is important for calculating the capacity of larger systems that include excavators. As a production monitoring value, it is important from a management and economical point of view. Furthermore, analysing influential factors like working conditions, digging depth, tool condition, etc. enables savings in energy and fuel consumption, excavator maintenance and higher working efficiency. Recent research studies deal with optimal bucket trajectory with respect to bucket forces and digging energy consumption (Du and Dorneich, 2015; Kusmierczyk and Szlagowski, 2008). Some of them focus on the optimisation of digging depth and teeth angle of attack, also using energy and digging forces as criterion (Chen et al., 2013; Lee et al., 2008; Richardson-Little and Damaren, 2008). 


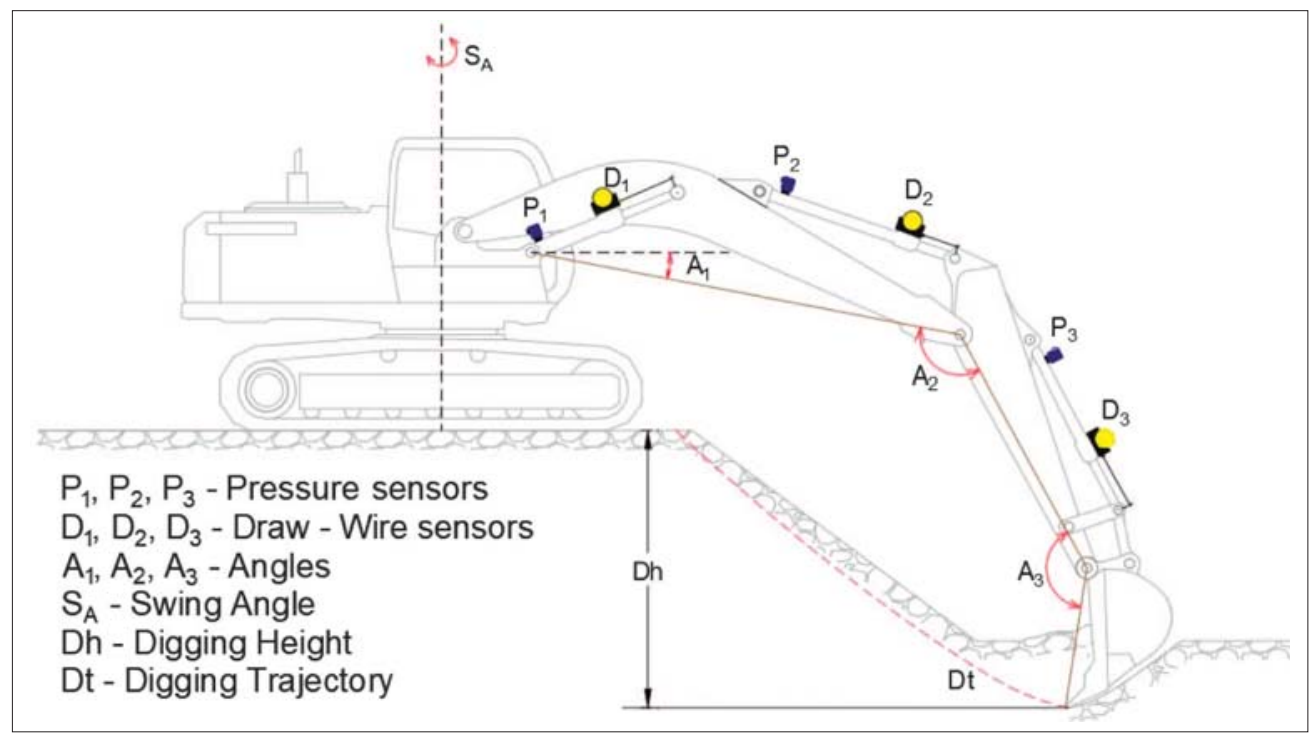

Figure 1: Measurement system mounting

Continuous measurement of productivity requires several elements to be measured simultaneously. If we consider excavator productivity as a mass/volume of material transferred in a unit of time, then simply the cycle time and bucket load are enough to calculate the productivity. Different approaches to estimate productivity can be more complex and require multiple elements to be known. Among them can be swing angle, excavation height or depth, slice depth and digging path length.

Likewise, to back analyze productivity, a measurement system must be able to measure those elements or provide values that can later be derived from.

\section{Measuring productivity and its components}

Depending on the measurement system, some values can be measured directly, such as swing angle, but most of them need to be derived.

Bucket load mass can be calculated from boom cylinder pressure as the difference between a full and empty bucket in the same position (Kim et al., 2013). Cylinder pressure is a function of bucket coordinates and bucket load weight. If the empty bucket function is known, then the weight difference of an empty to full bucket can be calculated in any position during the cycle. The transformation of pressure to bucket load weight will depend upon kinematic relations and the cylinder piston diameter. Additionally, load weight can be transformed to mass, or volume if bulk density of the material is known.

Bucket trajectory can be calculated from cylinder elongation and kinematic relations of the boom-armbucket system. The elongation of cylinders can be measured by draw-wire sensors (Kim et al., 2013) or by mag- netostrictive sensors (Vladeanu and Vladeanu, 2017). Many researchers have described the kinematics of a hydraulic excavator. Most of them presented DenavitHartenberg's analytical approach with the transformation matrix as a relation of coordinate frames positioned in joints (Koivo, 1994; Xu and Yoon, 2016; Spong et al., 2006). Bucket trajectory which directly depends on the kinematics of an excavator, can be shown with trigonometric equations on each link. Besides measuring cylinder elongation, another way to determine bucket position is to measure the relative angle at every joint in the boom-arm-bucket system. This approach was used by Feng et al. (2017). Including the swing angle to bucket trajectory gives a three-dimensional position of the bucket.

Knowing the bucket teeth trajectory enables the monitoring of different working parameters such as digging height or depth, cutting depth and length, swing angle and cycle time. Figure 1 presents possible working parameters along with the arrangement of the measuring system.

Cycle time usually requires observation, so the start and end bucket position can be determined. These positions will depend upon the type of operation that the excavator performs. During excavation and loading operations, start and end positions can be mathematically determined using the bucket vertical and horizontal position, with the addition of swing angle. A combination of their minimums and maximums during the cycle determines the start/end position.

\section{Elements of the measuring system}

The measurement system consists of three draw wire sensors, one for each cylinder elongation, and three pressure sensors. The sensor used for rotational swing is 
an inertial measurement unit (IMU) with the ability of absolute angular orientation. All sensors are connected to an Atmega328p based logger unit, equipped SD card module and 12-bit ADC converter, as shown in Figure 2. In addition, a Bluetooth module is mounted to enable wireless data transfer to a desktop PC or laptop.

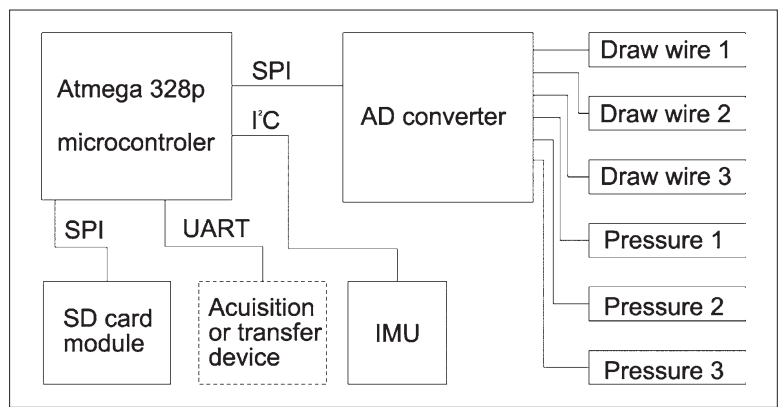

Figure 2: Block diagram of the measurement system

\subsection{Draw wire sensors}

Draw wire sensors are simple linear displacement measurement devices. Linear displacement is transformed into a rotational motion of the shaft via a wire (see Figure 3). Rotation of the shaft is measured by sensing an element, usually potentiometer or any kind of rotational encoder. In this case, potentiometric output was selected due to its simpler implementation and lower price. Such analog sensors can be powered by a wide range of voltage, which is convenient for field use with battery power sources. Their output is ratiometric, which means that the output signal is proportional to the power supply voltage. WPS-2300-MK88-CR-5 has a measuring range of $2300 \mathrm{~mm}$ and linearity below $0.15 \%$ FSO (MicroEpsilon, 2015). Potentiometric output gives quasi infinite resolution, which in turn depends upon the AD converter. Figure 3 shows the operational principle of a draw wire sensor (Stuhler, 2015) and its typical construction.

\subsection{Pressure transmitter}

Pressure transmitters are usually constructed with a membrane that deforms under pressure. This deformation can be measured using strain gauges and is related to the measured pressure value. Transmitters are available with a variety of output signals, including current output (4 mA-20 mA), millivoltage output, amplified voltage and ratiometric output. Most of these options require a power supply in the range from $8 \mathrm{~V}-30 \mathrm{~V}$. One exception found here is the ratiometric (3-wire) transmitter with 0.5 V-4.5 V output (Wika, 2011). It requires a nominal $5 \mathrm{~V}$ but can operate on lower voltages and possibly a bit higher than $5 \mathrm{~V}$. The output is $10 \%$ of the power supply voltage at zero pressure and $90 \%$ at the range maximum. This way the transmitter can operate on other voltages, but accuracy might be affected, since it is specified for $5 \mathrm{~V}$. Figure $\mathbf{4}$ shows a typical pressure transmitter and its operational principle.

\subsection{Analog to digital converter}

The AD converter used in this research is the Microchip MCP3008-BI/P. It is a 12-bit converter that can be configured as 8-channel single-ended inputs, or 4-chan-

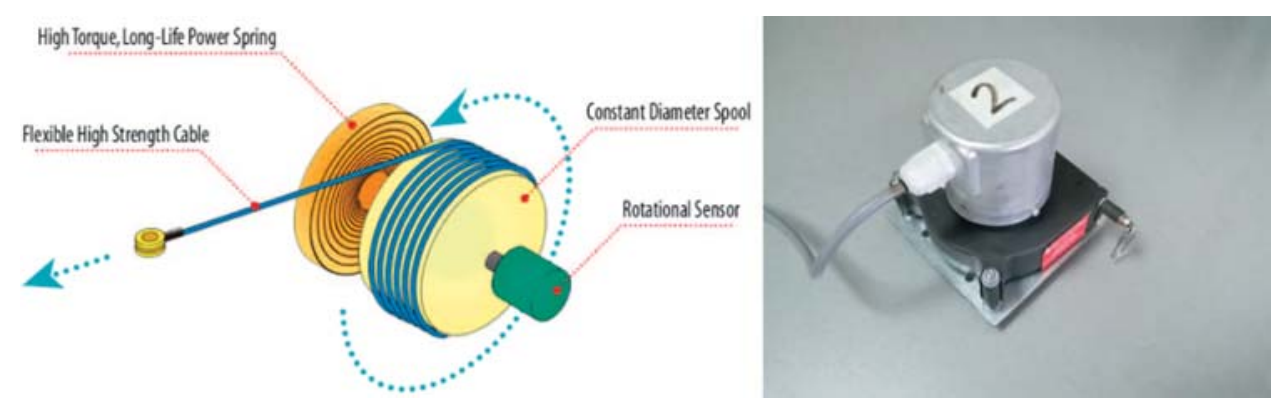

Figure 3: Draw wire sensor
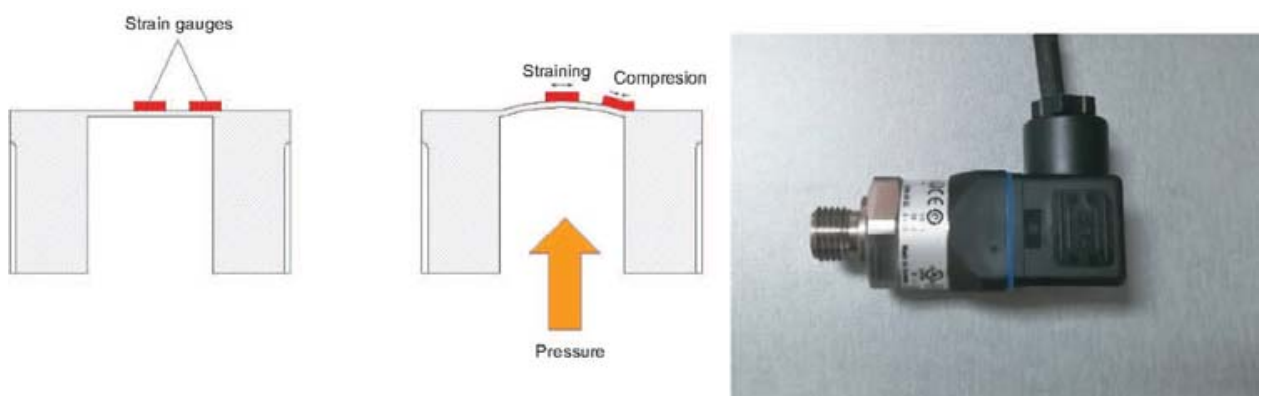

Figure 4: Pressure transmitter 


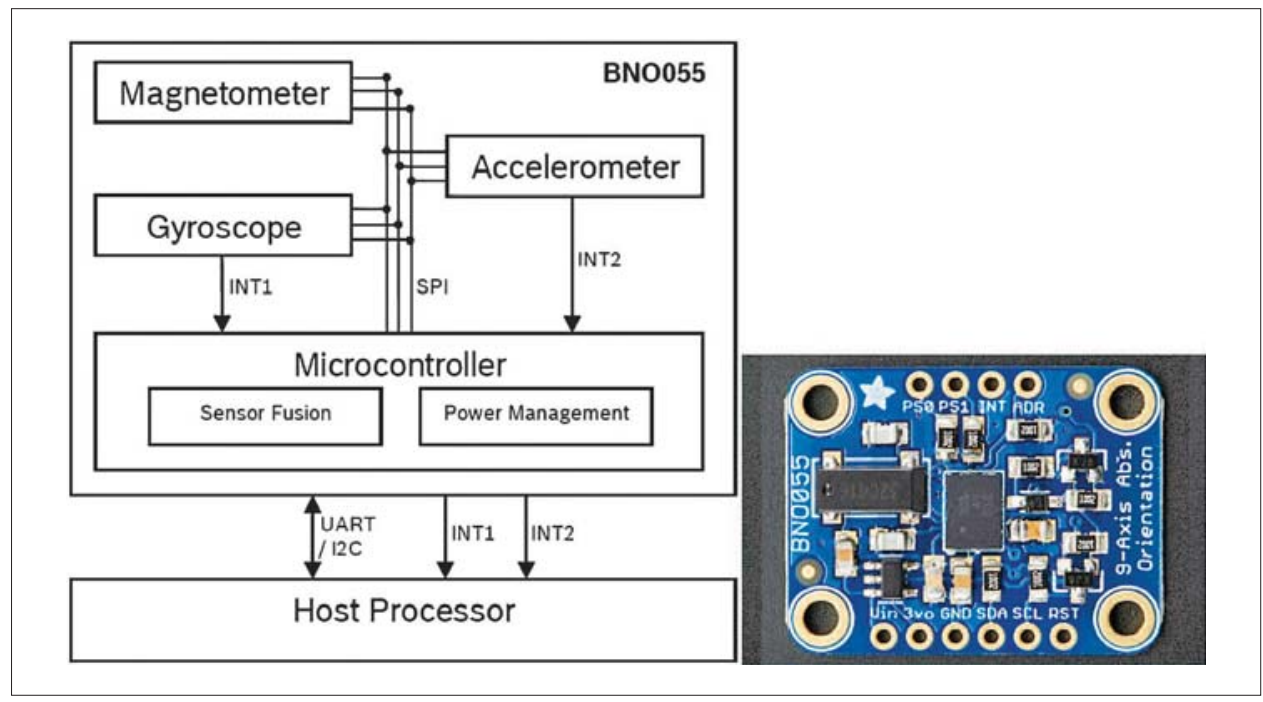

Figure 5: Inertial measurement unit BNOo55 (Bosh, 2014) and Adafruit PCB (Adafruit, 2018)

nel differential inputs (Microchip, 2002). It is designed for single supply operation voltages $2.7 \mathrm{~V}$ to $5.5 \mathrm{~V}$, which is very convenient for battery powered projects. It has a maximum sampling rate of $100 \mathrm{kSps}$. Maximum specified errors amount to 1 LSB for nonlinearity, 3 LSB for offset and 5 LSB for gain. The configuration of the converter and data acquisition is accomplished via 4-wire SPI interface.

\subsection{Inertial measurement unit}

Measuring the elongation of the cylinders can only be used to calculate position in the plane of the excavator's boom and arm. The means for the measurement of swing and excavator's tilt from horizontal plane are also needed in order to measure the 3-dimensional trajectory. The inertial measurement unit Bosch BNO055 is a combination of a three-axis gyroscope, accelerometer and magnetometer. A built-in microprocessor fuses the data from all three sensors and calculates the orientation. Raw data, relative orientation or absolute orientation can be acquired depending on the selected mode of operation (Bosch, 2014).

The chip itself normally operates at $3.3 \mathrm{~V}$, but the $\mathrm{PCB}$ is equipped with a voltage regulator and logic level converter and thus a voltage supply of up to $5 \mathrm{~V}$ can be applied. Communication with a microcontroller can be established via UART or I2C bus. Figure 5 shows an internal block diagram and PCB for BNO055.

\subsection{Logger unit}

A logger unit is an essential part of the measuring system which acquires measured values from sensors, does data processing as needed and forwards data to a storage unit or other communication devices. In this case, the logger unit is based on the Atmega328p microcontroller which controls all other elements of the system in ac- cordance to the uploaded code. The main idea is to loop through the procedure of reading all sensors' data, storing data to an SD card, then sending data to a Bluetooth module and repeating this procedure at defined time intervals. The addition of a Bluetooth module gives the ability to send data wirelessly to a computer, which in turn allows for data storage and/or real-time display of the measured values.

\section{Basic algorithm}

The developed logger unit is based on an Atmega328 microcontroller. It is the same microcontroller that the Arduino platform started from. This way the Arduino IDE with its already developed libraries and knowledge bases can be used to program the logger unit.

Arduino is an electronics platform used to read input and, if needed, turn the collected data into output. The best thing about Arduino is its low cost and easy-to-use hardware and software with an open-source community. It was developed from a project in 2005 whose goal was to enable fast prototyping, aimed at students without a background in electronics and programming. (Arduino, 2018).

The Arduino Integrated Development Environment or Arduino Software (IDE) - contains a text editor for writing code, a message area, a text console, a toolbar with buttons for common functions and a series of menus. It connects to the Arduino hardware to upload programs and communicate with them. Every IDE code contains two functions - setup and loop). The function setup() is the function that only runs once upon controller reset, to initialize variables, pin modes, start using libraries, etc. After creating a setup() function, which initializes and sets the initial values, the $\operatorname{loop}()$ function does precisely what its name suggests, and loops consecutively, allowing a program to change and respond 


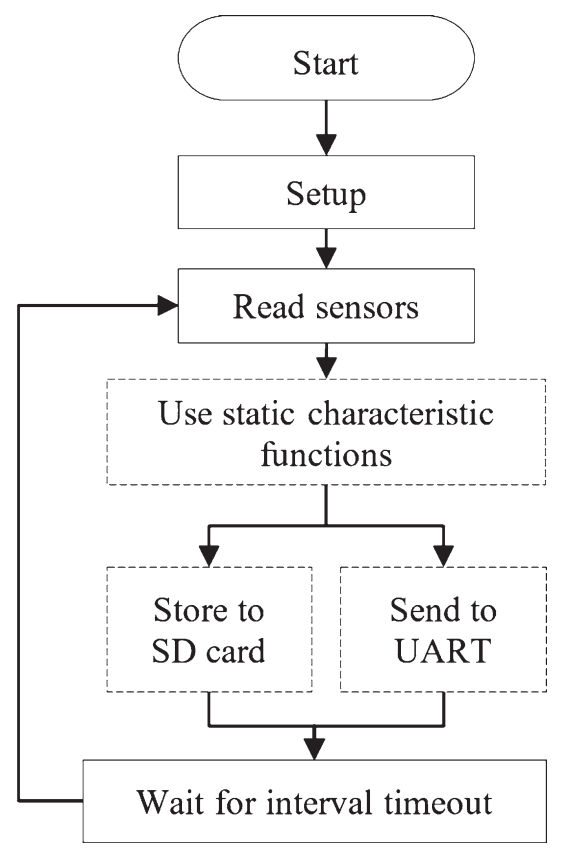

Figure 6: Logger unit algorithm

until reset of the board. It is used to actively control the Arduino board.

Possibilities with the Arduino board are immense because of its huge open-source community especially regarding the Arduino Software (IDE). That vast choice of possibilities is enabled by the use of libraries. Through the use of libraries, the environment of IDE can be extended, just like most programming platforms. Libraries provide extra functionality for use in sketches (written lines of code saved as a program), e.g. working with hardware or manipulating data.

The basic algorithm is shown in Figure 6. Several variants of the algorithm were used as a combination of three main options. One option is to give raw values (counts) from an $\mathrm{AD}$ converter versus using static characteristics in order to give data in measurement units. Floating point arithmetic is generally more demanding for a microcontroller, slowing down code execution and reducing the maximum sample rate that can be established. The other two options refer to data transfer and storage. Storage to an SD card and/or sending data to UART can be chosen. One of the latter options must be turned on to preserve measurement data, but both may be active as well. A combination will affect the maximum sample rate.

\section{Testing the measurement system}

The system was tested in laboratory conditions to determine the accuracy and usable sample rate. During the procedure, calibrated instruments were used as a reference to compare output values, including perforated steel tape, a precision protractor and a precision pressure acquisition system. Temperature drift and time drift are neglected in this case. Testing conditions were not allowing for this at the moment, but future tests can be performed in different conditions. All deviations from reference output are calculated regarding the best fit straight line, with the exemption of the draw wire sensor where polynomial regression was more appropriate to increase accuracy.

Draw wire sensors were tested using perforated steel tape with equally spaced perforations at $10 \mathrm{~mm}$ intervals. A typical response from the draw wire is presented in Figure 7 (left). Nonlinearity is obvious with this type of sensor. Slight hysteresis can also be observed as deviation is shifted, comparing output with the pulling and retracting direction. The static characteristic is used to convert raw sensor data, ADC counts in this case, into useful measurement units. The application of linear regression gives the static characteristic function presented in Figure 7 (left). The maximum error is found to be $\pm 6 \mathrm{~mm}$, or $0.26 \% \mathrm{FSO}$ in this case. An absolute error of $6 \mathrm{~mm}$ is acceptable considering the measurement range, but it might cause intolerable errors in certain positions of the excavator bucket. For this reason, polynomial regression is performed to give mathematical functions of the third order. This way, sensor nonlinearity is decreased and the maximum error drops to only $\pm 2 \mathrm{~mm}$ or $0.086 \%$ FSO, as presented in Figure 7 (right).

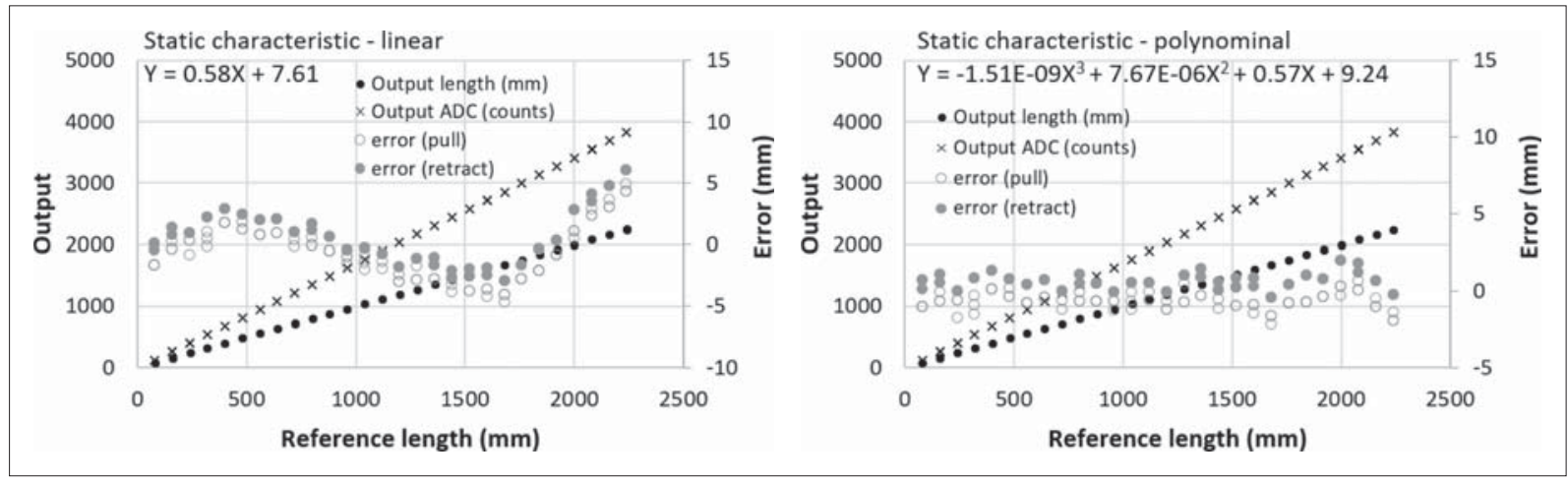

Figure 7: Draw wire calibration 
Pressure transmitters were tested in the range from 0 bar to 100 bar, since this is the limit of the reference transmitter. Testing was done applying two passes in the pressure rising direction and two passes in the pressure falling direction. Nonlinearity nor hysteresis can't be observed in this case (see Figure 8). Output shows only Gaussian distribution of error, probably caused by noise. These transmitters are found to have great linearity and a very low error of \pm 0.15 bar, or $0.026 \%$ FSO for the

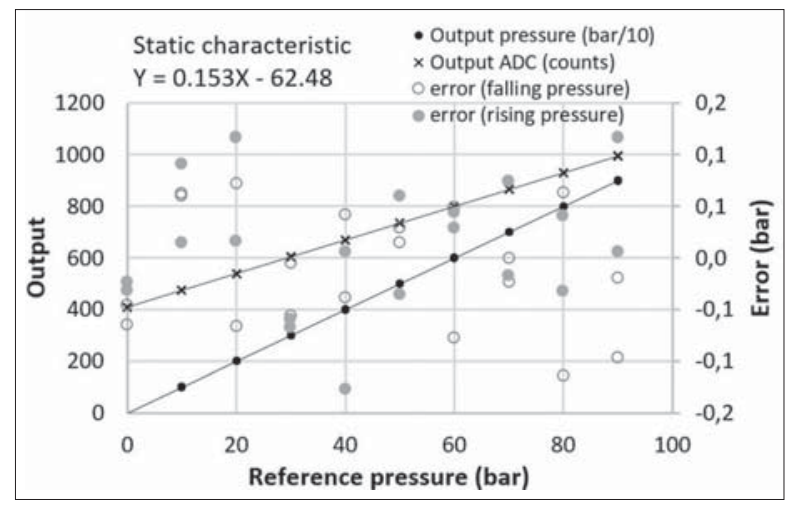

Figure 8 Pressure transmitter calibration tested range. Linear regression is more than enough for very accurate conversion to measurement units.

The BNO055 unit was tested in 'IMU Fusion' mode (Bosch, 2014) where only the accelerometer and gyroscope are active. Output data given this way is orientation relative to the position during power-up. The unit has a built-in magnetometer that could provide absolute orientation relative to the Earth's magnetic field, but it is assumed that the massive iron construction of an excavator would influence its accuracy and thus it's avoided in this case. A precision protractor was used as a reference device, testing with two passes in a right rotation and two passes in a left rotation. The unit outputs relative rotation directly, in the form of a signed 2-byte integer, where 16 bits represent one degree of rotation. The conversion to degrees is performed internally within the BNO055 library. As shown in Figure 9 (left), direct sensor output contains an offset of $6.7^{\circ}$ per circle. Slight hysteresis can be observed, but there is no apparent nonlinearity. To get more accurate readings, a correction function can be applied to the sensor output. Linear regression analysis gave the equation shown in Figure 9 (right). As can be seen, the correction function eliminates the offset and reduces the maximum error to $\pm 1.2^{\circ}$ or $0.33 \%$ FSO.

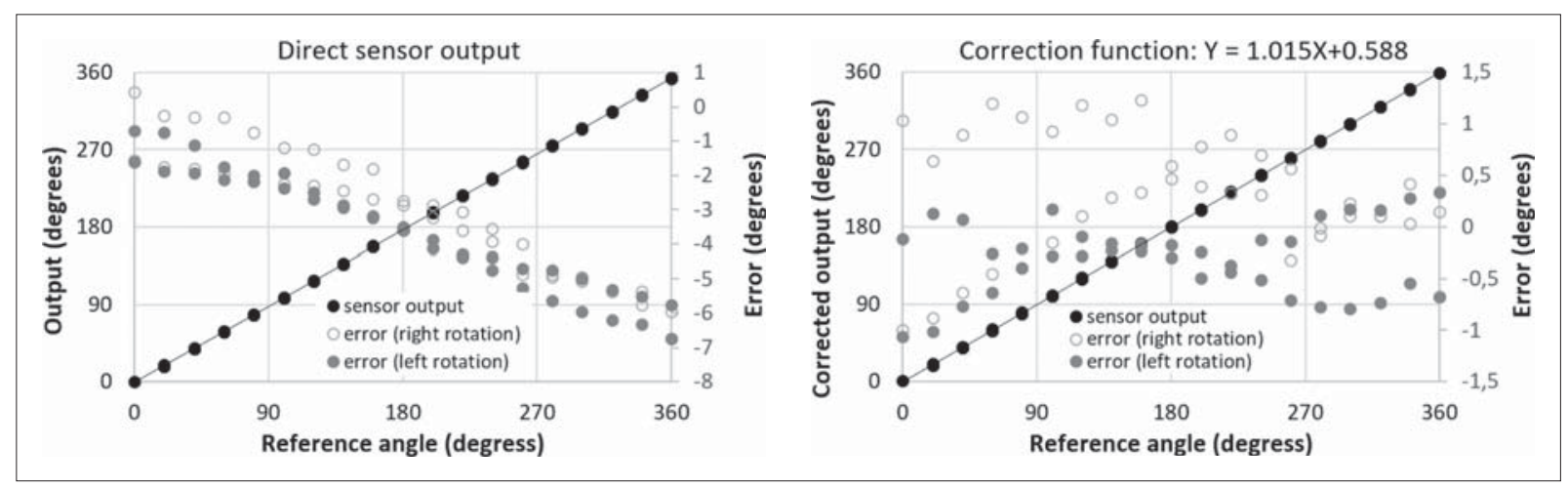

Figure 9: IMU unit calibration

Table 1: Measurement system characteristics

\begin{tabular}{|l|l|l|l|}
\hline & $\begin{array}{l}\text { Cylinder } \\
\text { pressure }\end{array}$ & $\begin{array}{l}\text { Cylinder } \\
\text { extension }\end{array}$ & Swing angle \\
\hline Accuracy & $0.026 \% \mathrm{FSO}$ & $0.087 \% \mathrm{FSO}$ & $0.33 \% \mathrm{FSO}$ \\
\hline Resolution & $0.15 \mathrm{bar}$ & $0.58 \mathrm{~mm}$ & $\begin{array}{l}0.0625^{\circ} \\
\left(16 \mathrm{LSB}=1^{\circ}\right)\end{array}$ \\
\hline Range & 0 bar-500 bar & $0 \mathrm{~mm}-2400 \mathrm{~mm}$ & $0^{\circ}-360^{\circ}$ \\
\hline
\end{tabular}

Table 2: Maximum sample rate

\begin{tabular}{|l|l|l|}
\hline & Raw Data & $\begin{array}{l}\text { Characteristic } \\
\text { Functions }\end{array}$ \\
\hline No Data (read sensors only) & $588 \mathrm{~Hz}$ & $588 \mathrm{~Hz}$ \\
\hline UART only & $344 \mathrm{~Hz}$ & $172 \mathrm{~Hz}$ \\
\hline SD Storge only & $58 \mathrm{~Hz}$ & $51 \mathrm{~Hz}$ \\
\hline UART + SD Storage & $56 \mathrm{~Hz}$ & $39 \mathrm{~Hz}$ \\
\hline
\end{tabular}

Different code options were tested for usable sample rates, as explained in Chapter 4. The highest sample rate is achieved while reading sensors without any data processing or storage. Sending data to a serial port is the fastest option for data transfer, while storage to an SD card slows down code execution multiple times. Using mathematical functions with floating point arithmetic also reduces the sample rate significantly, which can be observed while sending data to UART only. Tables 1 and 2 summarize the testing results.

\section{Discussion and conclusions}

Testing of the system was carried out with neglected temperature and time drift, since laboratory conditions were not allowing for more complex tests. These can be 
performed at a later time as necessary, with different temperature conditions and after a period of usage.

Accuracy of the pressure transmitters is excellent despite a power supply of $3.7 \mathrm{~V}$, as they are declared to operate on $5 \mathrm{~V}$. They were tested in the range of $100 \mathrm{bar}$ because of the reference transmitter limitation, but we assume that acceptable accuracy is retained through the full range.

Draw wire sensors have acceptable accuracy, considering the needed measurement range. Nevertheless, an absolute error of $6 \mathrm{~mm}$ in cylinder elongation could cause unacceptable inaccuracy in the determination of the bucket teeth coordinates. This may happen for certain bucket positions in the boom-arm-bucket kinematic system, where angles between triangles are narrow. For this reason, a polynomial static characteristic is created, which offers more accurate readings.

Direct output of the inertial measurement unit shows a drift error of $6.7^{\circ} /$ circle. This is acceptable for the swing angle measurement, since the excavator rarely turns multiple times, but rather changes direction twice per cycle. Nevertheless, to maintain accuracy in case of multiple turns, a correction function is created that allows for accuracy better than $1.2^{\circ}$

The lowest achieved sample rate of the logger unit is $39 \mathrm{~Hz}$. This is found to be more than enough compared to the excavator cycle, which typically amounts to more than $20 \mathrm{~s}$. This gives at least 780 data points within one cycle. Higher sample rates can be achieved by removing SD storage, depending on data transfer options via UART. Another way is to remove static characteristic functions from the algorithm, but this is at the expense of accuracy. In this case, raw data can be processed afterwards.

Laboratory testing proved the measurement system to be functional and acceptably accurate, also having required measurement ranges and a sampling rate. Further research should be performed in the field to validate the system in different conditions and test for its reliability. Special concerns may be vibrations, temperature conditions and battery life.

\section{References}

\section{Published}

Antoljak, D., Kuhinek, D., Korman, T. and Kujundžić, T. (2018): Dependency of Specific Energy of Rock Cutting on Specific Drilling Energy. The Mining-Geology-Petroleum Engineering Bulletin. 33(3), 23-32. (DOI: 10.17794/ rgn.2018.3.3)

Chen, J., Qing, F. and Pang, X. (2013): Mechanism optimal design of backhoe hydraulic excavator working device based on digging paths. Journal of Mechanical Science and Technology, 28, 213-222. (DOI: 10.1007/s12206-0130955-4)
Du, Y., Dorneich, M. C. and Steward, B. (2016): Virtual operator modeling method for excavator trenching. Automation in Construction, 70, 14-25. (DOI: 10.1016/j.autcon.2016.06.013)

Feng, H., Yin, C. B., Weng W. W., Maa, W., Zhou J. J., Jia, W. H., Zhang, Z. L. (2018): Robotic excavator trajectory control using an improved GA based PID controller. Mechanical Systems and Signal Processing, 105, 153-168 (DOI: 10.1016/j.ymssp.2017.12.014)

Kim, B. Y., Ha, J., Kang, H., Kim, P. Y., Park, J., Park, F.C. (2013): Dynamically optimal trajectories for earthmoving excavators. Automation in Construction. 35, 568-578 (DOI: 10.1016/j.autcon.2013.01.007)

Koivo, A. J. (1994): Kinematics of excavators (backhoes) for transferring surface material. Journal of Aerospace Engineering. 7, 17-32. (DOI: 10.1061/(ASCE)08931321(1994)7:1(17))

Korman, T., Kujundžić, T., Klanfar, M. (2015): Analysis of Constructional and Operational Parameters of Chain Saw. The Mining-Geology-Petroleum Engineering Bulletin. 30 (1), 45-54. (DOI: 10.17794/rgn.2015.1.5)

Kusmierczyk, J. and Szlagowski, J. (2008): Automated excavation process analysis for given trajectory and soil parameters. In: Skibniewsk, M. J., et. al. (eds.): International Symposium on automation and Robotics in Construction., 95-99, 285 p. (DOI: 10.3846/isarc.20080626.95)

Kwon, S. K., Kim, J. J., Jung, Y. M., Jung, C. S., Lee, C. D. and Yang, S. Y. (2008): A hydraulic simulator for an excavator. In: anon (eds): Proceedings of JFPS International Symposium on Fluid Power., 611-616. (DOI:10.5739/ isfp.2008.611)

Lee, S., Hong, D., Park, H., and Bae, J. (2008): Optimal Path Generation for Excavator with Neural Networks Based Soil Models. In: Lee, S., Hanseok, K., Hernsoo, H., (Eds.): IEEE International Conference on Multisensor Fusion and Integration for Inteligent Systems., 623-637, (DOI: 10.1109/MFI.2008.4648015)

Mitrev, M., Janošević, D. and Marinković, D. (2017): Dynamical modeling of hydraulic excavator considered as a multibody system. Technical Gazette, 24, 327-338. (DOI:10.17559/TV-20151215150306)

Richardson-Littl, W. and Damaren, C. (2008): Position Accommodation and Compliance Control for Robotic Excavation. Journal of aerospace engineering, 21, 27-34. (DOI 10.1061/(ASCE)0893-1321(2008)21:1(27))

Spong, M. W., Hutchinson, S., and Vidyasagar, M. (2005): Robot Modeling and Control. John Wiley and Sons. New York, 407 p. (DOI: 10.1109/MCS.2006.252815)

Vladeanu, A. and Vladeanu, G. (2017): The displacement of excavator bucket on the optimum trajectory through the control of hydraulic cylinders lengths. Romanian Journal of Technical Sciences. 62, 105-117.

$\mathrm{Xu}$, J., and Yoon, H. S. (2016): A Review on Mechanical and Hydraulic System Modeling of Excavator Manipulator System. Journal of Construction Engineering. 2016, 11p. (DOI: 10.1155/2016/9409370)

The Mining-Geology-Petroleum Engineering Bulletin and the authors @, 2019, pp. 51-58, DOI: 10.17794/rgn.2019.2.6 


\section{Unpublished}

Bosch (2014): BNO055 Intelligent 9-axis absolute orientation sensor. Bosch Sensortec GmbH, Reutlingen.

Microchip (2002): 2.7V 4-Channer/8-Channel 12-Bit A/D Converters with SPI Serial Interface - MCP304/3208 datasheet. Microchip Technology Inc. Chandler.

MicroEpsilon (2015): Draw wire displacement sensors - instruction manual. Micro-epsilon Messtechnik GmbH \& Co. Ortenburg.

Wika (2011): Pressure transmitter for general industrial applications - A10 datasheet. Wika instrument Corporation, Lawrencewille.

\section{Internet sources}

Adafruit (2018): BNO055. URL: https://learn.adafruit.com/ adafruit-bno055-absolute-orientation-sensor/overview (accessed 29th August 2018)

Arduino (2017): Arduino Guide. URL: https://www.arduino. cc/en/Guide/HomePage (accessed 29th August 2018)

Arduino (2018): Arduino Libraries. URL: https://www.arduino.cc/en/Reference/Libraries (accessed 29th August 2018)

Stuhler, M. (2015): Draw wire sensors revisited. URL: https: //www.cpi-nj.com/blog/draw-wire-sensors-revisited (accessed 29th August 2018)

\section{SAŽETAK}

\section{Konstrukcija i ispitivanje sustava za praćenje učinka bagera}

Hidraulični bager jedan je od najčešće korištenih strojeva u rudarstvu, graditeljstvu i geotehnici. Kao takav korisnicima predstavlja i važnu stavku u troškovima goriva i održavanja. Detaljna mjerenja učinka ovoga stroja izvode se u svrhu poboljšanja efikasnosti odnosno uštede. Mjerni sustav s takvom svrhom može biti složen i skup, tražiti specijalnu opremu proizvođača stroja te ne postoji kao gotovo rješenje koje bi omogućavalo praćenje radnih parametara poput trajektorije lopate, sila i energije kopanja, visine radnoga čela i sl.

Iz toga razloga osmišljen je i testiran sustav za praćenje radnih parametara i učinka bagera. Sustav se sastoji od triju pretvornika linearnoga pomaka i triju pretvornika tlaka, za mjerenje produljenja i tlakova hidrauličnih cilindara, te jednoga žiroskopa za mjerenje kuta zakretanja bagera. Pretvornici su spojeni na jedinicu za prikupljanje podataka, opremljenu SD karticom i 12-bitnim AD pretvaračem. Jedinica je bazirana na Atmegaz28 mikrokontroleru, što omogućava primjenu Arduino sučelja za programiranje i razvijenih biblioteka koda.

Mjerni sustav testiran je laboratorijski radi određivanja točnosti, rezolucije i moguće brzine uzorkovanja podataka. Tlakovi mogu biti mjereni u rasponu o bar - 500 bar s točnošću od o,026 \% MO i rezolucijom o,15 bar. Izvlačenje cilindra može biti mjereno u rasponu o mm - 2300 mm, s točnošću od o,o87 \% MO i rezolucijom o,58 mm. Točnost mjerenja kuta zakretanja iznosi $1,2^{\circ}$ po okretu ili o,33\% MO. Testirana brzina uzorkovanja iznosi $39 \mathrm{~Hz}-588 \mathrm{~Hz}$, ovisno o programskome kodu.

Ključne riječi:

rudarstvo, bager, učinkovitost, mjerni sustav

\section{Authors contribution}

Mario Klanfar (Assistant Professor) initialized the idea and lead the research with contribution in component selection, measurement system assemblage and programming. Vjekoslav Herceg (Assistant) compiled state of the art research and methods in the measurement of excavator productivity and contributed to measurement system testing. Dalibor Kuhinek (Associate Professor) contributed to measurement system assemblage, testing of the system, setting up the calibration system and data analysis. Kristijan Sekulić (Student) assisted in laboratory testing and did research on usage of the Arduino IDE and libraries to program the logger unit. 